\title{
ЗАПОБІГАННЯ ТА ПРОТИДІЯ ДИСКРИМІНАЦІЇ В ПЕНСІЙНІЙ СИСТЕМІ УКРАЇНИ
}

\author{
Боднарук М. І., Бурка А. В.
}

\section{ВСТУП}

Принципи рівноправності та заборони дискримінації - одні з основоположних принципів права, без яких неможливе формування й існування демократичного, соціального суспільства та побудова правової системи, у якій утвердження та забезпечення прав і свобод людини є головним обов'язком держави. Майбутнє кожної країни залежить від пріоритетних напрямів державної політики, як внутрішньої, так i зовнішньої․․․ Прагнення України брати активну участь в європейських інтеграційних процесах зумовлює необхідність реформування iї правової системи відповідно до європейських стандартів ${ }^{2}$. На сучасному етапі відносини між Україною та Європейським Союзом (далі (C) розвиваються в напрямі євроінтеграції. У зв'язку із цим, на нашу думку, видається актуальним та доцільним проведення аналізу нормативно-правового регулювання гарантування та втілення на практиці принципів рівності та заборони дискримінації у сфері соціального забезпечення, а саме пенсійного забезпечення, як такій, що є однією 3 найбільш уразливих до проявів непрямої дискримінації, гендерної нерівності, оскільки досить часто останні приховуються під поняттям «диференціація». Окрім цього, вищезазначений аналіз дозволить дослідити прогрес національного законодавства щодо запозичення досвіду СС і утвердження загальновизнаних норм і принципів (антидискримінаційного характеру) у правовій системі України.

Реалізація антидискримінаційної державної політики покладає на кожну державу обов'язок забезпечення реалізації низки позитивних заходів, першим із яких є, зокрема, розроблення й ухвалення відповідних законів, актів підзаконного характеру чи доповнення вже чинних нормативно-правових актів окремими положеннями.

Відповідно до Угоди про асоціацію між Україною та $\mathrm{EC}$, в Україні відбувається активний процес реформування законодавства в соціальній сфері. Урядом ухвалені нормативно-правові акти, які

\footnotetext{
1 Чічкань М., Бабіч К. Європейські стандарти щодо заборони дискримінації у сфері праці та законодавство України: питання співвідношення. Порівняльно-аналітичне право. 2016. № 5. С. 164.

2 Богачева Л. Джерела європейського та національного права. Державне будівниитво та місиеве самоврядування. 2012. Вип. 24. С. 17.
} 
сприятимуть ефективній реалізації Угоди про асоціацію. Так, у березні 2016 р. Україна ратифікувала Конвенцію Міжнародної організації праці про мінімальні норми соціального забезпечення № 102. У листопаді 2016 р. відбулося укладення Європейського кодексу соціального забезпечення. У 2018 р. затверджено Державну соціальну програму забезпечення рівних прав та можливостей жінок і чоловіків на період до 2021 p. $^{3}$ Розпорядженням Кабінету Міністрів України (далі - КМУ) від 5 вересня 2018 р. № 634-р було затверджено Національний план дій з виконання рекомендацій, викладених у заключних зауваженнях Комітету Організації Об'єднаних Націй (далі - ООН) із ліквідації дискримінації щодо жінок до восьмої періодичної доповіді України про виконання Конвенції про ліквідацію всіх форм дискримінації щодо жінок на період до 2021 p. ${ }^{4}$

Суттєвим кроком до створення механізму протидії дискримінації, на думку розробників, має стати ухвалення законопроєкту «Про внесення змін до деяких законодавчих актів України (щодо гармонізації законодавства у сфері запобігання та протидії дискримінації із правом Свропейського Союзу)» № 3501 від 20 листопада 2015 р.) $)^{5}$. Ухвалення законопроєкту необхідне з погляду як реалізації Угоди про асоціацію, так і наближення до практики європейських країн у питаннях, які він регулює.

У 2019 р. також було досліджено стан імплементації та відповідність нормам законодавства України трьох із шести антидискримінаційних Директив СС, які потребують першочергового впровадження у країні відповідно до Угоди про асоціацію: Директиви № 79/7/СЕС від 19 грудня 1978 р.; Директиви № 92/85/СЕС від 10 жовтня 1992 р.; Директиви Ради 2004/113/ЄС від 13 грудня 2004 р.

\footnotetext{
3 Про затвердження Державної соціальної програми забезпечення рівних прав та можливостей жінок і чоловіків на період до 2021 р. : постанова КМУ від 11 квітня 2018 р. № 273. База даних «Законодавство України». URL: https://zakon.rada.gov.ua/laws/show/273-2018-п (дата звернення: 24.02.2020).

4 Про затвердження Національного плану дій з виконання рекомендацій, викладених у заключних зауваженнях Комітету ООН з ліквідації дискримінації щодо жінок до восьмої періодичної доповіді України про виконання Конвенції про ліквідацію всіх форм дискримінації щодо жінок на період до 2021 р. : розпорядження КМУ від 5 вересня 2018 р. № 634-p. База даних «Урядовий портал». URL: https://www.kmu.gov.ua/npas/pro-go-planudij-z-vikonannya-rekomo-zhinok-do-vosmoyi-periodichnoyi-dopovidi-ukrayini-pro-vikonannyakonvenciyi-pro-likvidaciyu-vsih-form-diskriminaciyi-shchodo-zhinok-na-period-do-2021-roku (дата звернення: 15.02.2020).

5 Про внесення змін до деяких законодавчих актів України (щодо гармонізації законодавства у сфері запобігання та протидії дискримінації із правом Європейського Союзу) : проєкт закону від 20 листопада 2015 р. № 3501 / Верховна Рада України. URL: http://w1.c1.rada.gov.ua/pls/zweb2/webproc4_1?pf3511=57162 (дата звернення: 19.02.2020).
} 


\section{1. Дискримінація за місцем проживання в пенсійній системі України}

Натепер, відповідно до чинного пенсійного законодавства України, особа має право на призначення, отримання заробленої пенсії незалежно від місця іiі проживання. Якщо ж органи Пенсійного фонду України відмовили у призначенні пенсій громадянам, які постійно проживають за кордоном, то така особа може звернутись до адміністративного суду з позовом про зобов'язання органу Пенсійного фонду України призначити пенсію. На перший погляд, це «звичайна» норма права, яка передбачає абсолютно зрозумілий обов'язок держави надавати пенсійне забезпеченням особам, що мають необхідний страховий стаж, досягли зазначеного пенсійного віку (відповідно до національного законодавства) чи відповідають іншим критеріям (залежно від виду пенсіі), але за тих чи інших обставин проживають за кордоном. Проте до 7 жовтня 2009 р. частина пенсіонерів, які постійно проживали за кордоном, були позбавлені свого права на отримання пенсії.

У Законі України «Про загальнообов'язкове державне пенсійне страхування» (до 7 жовтня 2009 р.) було визначено, що виплата пенсії пенсіонерам припиняється на час їх постійного проживання за кордоном у разі, якщо Україна не уклала з відповідною державою міжнародний договір $з$ питань пенсійного забезпечення і якщо згода на обов'язковість такого міжнародного договору не надана Верховною Радою України ${ }^{6}$ Виняток існував лише для осіб, які отримували пенсії внаслідок трудового каліцтва або професійного захворювання, останнім пенсії виплачувалися незалежно від наявності чи відсутності міжнародного договору (ч. 2 ст. 92 Закону України «Про пенсійне забезпечення» ${ }^{7}$ ). Тобто йшлося про очевидну дискримінацію прав пенсіонерів, і це тоді, коли відповідно до ст. 7 Закону України «Про загальнообов'язкове державне пенсійне страхування» загальнообов'язкове державне пенсійне страхування здійснюється на принципі рівноправності застрахованих осіб щодо отримання пенсійних виплат ${ }^{8}$.

\footnotetext{
6 Про загальнообов'язкове державне пенсійне страхування : Закон України від 9 липня 2003 р. № 1058-IV, у редакції від 5 листопада 2008 р. / Верховна Рада України. URL: https://zakon.rada.gov.ua/laws/show/1058-15/ed20081105 (дата звернення: 17.02.2020).

7 Про пенсійне забезпечення : Закон України від 5 листопада 1991 р. № 1788-XII, у редакції від 1 січня 2008 р. / Верховна Рада України. URL: https://zakon.rada.gov.ua/laws/ show/1788-12/ed20080101 (дата звернення: 16.01.2020).

8 Про загальнообов'язкове державне пенсійне страхування : Закон України від 9 липня 2003 р. № 1058-IV / Верховна Рада України. URL: https://zakon.rada.gov.ua/laws/show/ 1058-15 (дата звернення: 18.02.2020).
} 
Не бралися до увагий положення Загальної деклараціїправ людини, відповідно до якої всі люди рівні перед законом і мають право, без будь-якої різниці, на рівний їх захист законом: усі люди мають право на рівний захист від будь-якої дискримінації9; Міжнародної конвенції про ліквідацію всіх форм расової дискримінації ${ }^{10}$; Свропейської соціальної хартії (переглянутої) від 3 травня 1996 р., ратифікованої Законом України від 14 вересня 2006 р. № 137-V, яка набрала чинності 31 лютого 2007 р. (далі - Хартія), а саме положення ст. 12, відповідно до якої сторони зобов'язуються вживати заходів для забезпечення: рівності між їхніми власними громадянами та громадянами інших сторін у тому, що стосується прав на соціальне забезпечення, включаючи збереження пільг, які надаються законодавством про соціальне забезпечення, незалежно від пересування захищених осіб по територіях держав сторін ${ }^{11}$.

Що лягло в основу такого дискримінаційного поділу пенсіонерів на дві категорії: 1) яким пенсії не виплачувалися, за відсутності міжнародного договору та 2) яким пенсії виплачувалися і за відсутності міжнародного договору, незрозуміло. Очевидно, що наявність чи відсутність трудового каліцтва, професійного захворювання, не може розцінюватися як об' єктивна й обгрунтована підстава для таких дій, за своєю природою це є дискримінацією.

Переломним у вирішенні цієї проблеми стало рішення Конституційного Суду України від 7 жовтня 2009 р. у справі № 1-32/2009 ${ }^{12}$. Конституційний Суд зробив висновок щодо неконституційності положень п. 2 ч. 1 ст. 49, другого речення ст. 51 Закону України «Про загальнообов'язкове державне пенсійне страхування».

Закріплюючи на конституційному рівні право на соціальний захист кожного громадянина, без будь-яких винятків,д ержава реалізує положення ст. 24 Конституції України, відповідно до яких громадяни мають рівні конституційні права і не може бути обмежень за ознаками

\footnotetext{
9 Загальна декларація прав людини, прийнята і проголош. резолюцією 217 А (III) Генеральної Асамблеї ООН від 10 грудня 1948 р. База даних «Законодавство Украӥни». URL: http://zakon.rada.gov.ua/laws/show/995_015 (дата звернення: 29.01.2020).

10 Міжнародна конвенція про ліквідацію всіх форм расової дискримінації від 21 грудня 1965 р. База даних «Законодавство Украӥни». URL: https://zakon.rada.gov.ua/laws/ show/995_105 (дата звернення: 01.02.2020).

11 Європейська соціальна хартія від 3 травня 1996 р. База даних «Законодавство України». URL: https://zakon.rada.gov.ua/laws/show/994_062 (дата звернення: 15.02.2020).

12 Рішення Конституційного Суду України від 7 жовтня 2009 р. у справі № 1-32/2009. База даних «Законодавство України». URL: https://zakon.rada.gov.ua/rada/show/v025p710-09/ ed20150101/sp:max25?sp=:max25\&lang=ru (дата звернення: 12.02.2020).
} 
раси, кольору шкіри, політичних, релігійних та інших переконань, статі, етнічного та соціального походження, майнового стану, місця проживання, за мовними або іншими ознаками. Отже, держава, усупереч конституційним гарантіям соціального захисту для всіх осіб, що мають право на отримання пенсії у старості, на законодавчому рівні позбавила цього права пенсіонерів у тих випадках, коли вони обрали постійним місцем проживання країну, з якою не укладено відповідного міжнародного договору.

Посилання аналогічного дискримінаційного змісту були виявлені і у ст. 3 Основ законодавства України про загальнообов'язкове державне соціальне страхування; у ч. 3 ст. 1, ч. 2 ст. 92 Закону України «Про пенсійне забезпечення», ч. 1 ст. 59-1 Закону України «Про статус і соціальний захист громадян, які постраждали внаслідок Чорнобильської катастрофи». Тому Конституційний Суд України звернув увагу Верховної Ради України і на необхідність узгодження з Конституцією України положень вищезазначених законів.

Здавалося б, що дане питання вирішено й аналогічні порушення прав пенсіонерів станом натепер не повинні виникати. Проте це далеко не так. Як показує практика, в Україні і надалі має місце порушення базових принципів здійснення пенсійного забезпечення. Цей факт також підтверджується низкою судових рішень за останні роки, у доповіді Уповноваженого з прав людини за 2018 р., де зазначено, що до Уповноваженого постійно надходять скарги 3 питань невиплати пенсій пенсіонерам за час їх постійного місця проживання за кордоном, якщо Україна не уклала $з$ відповідною державою міжнародного договору з питань пенсійного забезпечення і якщо згода на обов'язковість такого міжнародного договору не надана Верховною Радою України ${ }^{13}$.

Якщо проаналізувати практику Верховного Суду щодо розгляду даної категорії справ, то загалом вона $є$ позитивною (постанова Верховного Суду України від 12 травня 2015 р. у справі № 21-180a15, постанова Верховного Суду України від 19 травня 2015 р. у справі № 21-168а15, постанова Верховного Суду від 18 вересня 2018 р. у справі № 522/535/17, постанова Верховного Суду від 19 вересня 2018 р. у справі № 766/1519/17, постанова Верховного Суду від 31 січня 2019 р. у справі № 520/9721/16-а, постанова Верховного Суду

\footnotetext{
13 Про стан додержання та захисту прав і свобод людини і громадянина України: щорічна доповідь Уповноваженого Верховної Ради України з прав людини. 2018 p. URL: http://www.ombudsman.gov.ua/ua/page/npm/info/ (дата звернення: 25.01.2020).
} 
від 12 березня 2019 р. у справі № 127/2126/17, постанова Верховного Суду від 13 червня 2019 р. у справі № 204/1134/17 (2a/204/91/17)).

Так, під час розгляду даної категорії справ Верховний Суд, окрім іншого, враховує: 1) положення ст. 1 Першого протоколу до Конвенції про захист прав людини і основоположних свобод від 4 листопада 1950 р.: кожна фізична або юридична особа має право мирно володіти своїм майном. Ніхто не може бути позбавлений своєї власності інакше як в інтересах суспільства і на умовах, передбачених законом і загальними принципами міжнародного права ${ }^{14} ; 2$ ) практику Європейського суду з прав людини (далі - ССПЛ) щодо розгляду справ стосовно порушення права володіння майном, де поняття «майно», як і «власність», має досить широке тлумачення й охоплює цілу низку економічних інтересів (активів) - як матеріальних, так і нематеріальних, включає в себе право на пенсію та соціальні виплати (справа «Міллер проти Австрії», заява № 5849/72; справа «Гайгузус проти Австрії», заява № 17371/90; справа «Стек та інші проти Сполученого Королівства», заяви №№ 65731/01 та 65900/015; 3) положення Закону України «Про свободу пересування та вільний вибір місця проживання в Україні», де встановлено, що реєстрація місця проживання чи місця перебування особи або їі відсутність не можуть бути умовою реалізації прав і свобод, передбачених Конституцісю, законами чи міжнародними договорами України, або підставою для їх обмеження ${ }^{16}$; 4) рішення ЄСПЛ у справі «Пічкур проти України», заява № 10441/06, що набрало статусу остаточного 7 лютого 2014 р., у якому було зроблено висновок, що право на отримання пенсії як таке стало залежним від місця проживання заявника. Це призвело до ситуації, у якій заявник, пропрацювавши багато років у своїй країні та сплативши внески до системи пенсійного забезпечення, був зовсім позбавлений права на пенсію лише на тій підставі, що він більше не проживає на території України (п. 51 цього рішення) ${ }^{17}$; 5) положення висновку № 11 (2008р.) Консультативної ради

\footnotetext{
14 Конвенція про захист прав людини і основоположних свобод від 4 листопада 1950 p. База даних «ЗаконодавствоУкраӥни». URL: https://zakon.rada.gov.ua/laws/show/995_004 (дата звернення: 27.01.2020).

15 Постанова Верховного Суду від 18 вересня 2018 р. у справі № 522/535/17. URL: https://zakononline.com.ua/court-decisions/show/84621472 (дата звернення: 15.01.2020).

16 Про свободу пересування та вільний вибір місця проживання в Україні : Закон України від 11 грудня 2003 р. № 1382-IV / Верховна Рада України. URL: https://zakon.rada.gov.ua/laws/ show/1382-15 (дата звернення: 17.01.2020).

17 Рішення Європейського суду з прав людини у справі «Пічкур проти України» від 7 листопада 2013 р., заява № 10441/06. База даних «Законодавство України». URL: https://zakon.rada.gov.ua/laws/show/974_984 (дата звернення: 29.01.2020).
} 
європейських суддів щодо якості судових рішень (п. п. 32-41), у якому, серед іншого, звертається увага на те, що всі судові рішення повинні бути обгрунтованими, зрозумілими, викладеними чіткою і простою мовою, і це $\epsilon$ необхідною передумовою розуміння рішення сторонами та громадськістю; 6) позицію ЄСПЛ (в аспекті оцінки аргументів учасників справи в касаційному провадженні), сформовану, зокрема, у справах «Салов проти України» (№ 65518/01; п. 89), «Проніна проти України» (№ 63566/00; п. 23), «Серявін та інші проти України» (№ 4909/04; п. 58): принцип, пов’ язаний із належним здійсненням правосуддя, передбачає, що в рішеннях судів та інших органів із вирішення спорів мають бути належним чином зазначені підстави, на яких вони грунтуються; 7) положення про те, що право не виникає внаслідок неправомірних дій (ex iniuriai us non oritur) або бездіяльності; держава не може відмовитися від виконання свого зобов'язання, посилаючись на підстави, які визнано незаконними; те, що право виникає з факту (ex facto jus oritur), не означає, що право може виникати з несправедливості (ex iniuria ius non oritur). Зазначені підходи застосовані ССПЛ, зокрема, у рішеннях: "Paradiso and Campanelli v. Italy" (№ 25358/12), "Sidabras and Others v. Lithuania" (№ 50421/08), "Ioannou v. Turkey" (№ 18364/91), “Schenk v. Switzerland” (№ 10862/84), “Stromblad v. Sweden” (№ 3684/07) ${ }^{18}$.

Як бачимо, під час розгляду вищезазначеної категорії справ досить активно використовується практика ЄСПЛ, яка, відповідно до ст. 17 Закону України «Про виконання рішень та застосування практики Свропейського суду з прав людини», є офіційним джерелом права.

\section{2. Гендерна нерівність у пенсійній системі України}

Гендерна рівність $є$ невід'ємною складовою частиною прав людини й умовою сталого розвитку країни. У демократичних суспільствах повинні бути гарантовані на рівні закону і створені умови для втілення на практиці можливостей чоловікам і жінкам однаковою мірою брати участь у всіх сферах життя та відповідно бути в них захищеними. Останні п’ятдесят років діяльність міжнародної спільноти спрямована на привернення уваги до питання гендерної рівності. Гендерна рівність визнається як цінність, якої слід досягнути адля справедливості та суспільного розвитку.

\footnotetext{
18 Постанова Верховного Суду від 1 жовтня 2019 р. у справі № 804/3646/18. Юридичний інтернет-ресурс «Протокол». URL: https://protocol.ua/ua/vs_kas_ukrainskiy_pensioner/ (дата звернення: 11.01.2020).
} 
Проголошення гендерної рівності цінністю передбачає досягнення рівного становища жінок і чоловіків у всіх сферах життєдіяльності суспільства шляхом правового забезпечення рівних прав жінок і чоловіків, ліквідації гендерної дискримінації, застосування спеціальних тимчасових заходів, спрямованих на усунення дисбалансу між можливостями жінок і чоловіків реалізовувати рівні права ${ }^{19}$. Незважаючи на позитивні результати СС у боротьбі з дискримінацією за ознакою статі, даний напрям діяльності і сьогодні залишається актуальним.

Для України питання гендерної рівності також залишається відкритим, зокрема у сфері пенсійного забезпечення. Упровадження принципів рівних прав та можливостей жінок і чоловіків $є$ однією з важливих умов європейської інтеграції України та виконання міжнародних зобов'язань згідно з основними міжнародними договорами у сфері захисту прав людини, зокрема Цілей сталого розвитку до 2030 р., затверджених Генеральною Асамблеєю $\mathrm{OOH}^{20}$.

Проблему недостатнього рівня впровадження принципу забезпечення рівних прав та можливостей жінок і чоловіків в Україні передбачається розв'язати шляхом застосуванням комплексного підходу та здійснення заходів, спрямованих на вдосконалення нормативно-правової бази, механізму проведення гендерно-правової експертизи та впровадження статистичних показників у сфері забезпечення рівних прав і можливостей жінок і чоловіків; виконання договірних та інших міжнародних зобов'язань щодо забезпечення рівних прав та можливостей жінок і чоловіків; поєднання політики гендерного інтегрування в усіх сферах життя і за всіма напрямами суспільного розвитку, поліпшення становища жінок у тих сферах, де існує нерівність тощо ${ }^{21}$, з урахуванням рекомендацій $\mathrm{OOH}$, Ради Європи, ЄС, Організації з безпеки і співробітництва в Європі (далі ОБСЄ), міжнародних моніторингових інституцій у сфері прав людини.

Велике значення для забезпечення принципу рівності чоловіків і жінок у сфері соціального забезпечення, зокрема і пенсійного забезпечення, має Директива СС № 79/7/СЕС від 19 грудня 1978 р.,

19 Гендерна політика Європейського Союзу: загальні принципи та найкращі практики. Київ, 2015. С. 6. Міжнародний центр перспективних досліджень (МЦПД). URL: http://www.icps.com.ua/assets/uploads/files/genderna_pol_tika_s.pdf (дата звернення: 25.02.2020).

20 Про стан додержання та захисту прав і свобод людини і громадянина України : щорічна доповідь Уповноваженого Верховної Ради України $з$ прав людини. 2018 р. URL: http://www.ombudsman.gov.ua/ua/page/npm/info/ (дата звернення: 25.01.2020).

21 Про затвердження Державної соціальної програми забезпечення рівних прав та можливостей жінок і чоловіків на період до 2021 р. : постанова КМУ від 11 квітня 2018 р. № 273. База даних «Законодавство Украӥни». URL: https://zakon.rada.gov.ua/laws/show/273-2018-п (дата звернення: 24.02.2020). 
що належить до низки Директив СС, які потребують першочергового впровадження в Україні. Директива охоплює державні системи обов' язкового соціального забезпечення, що передбачають захист від таких ризиків, як хвороба, інвалідність, старість, безробіття, нещасні випадки на виробництві та професійні захворювання.

Окрім Конвенції про ліквідацію всіх форм дискримінації щодо жінок, яку Україна ратифікувала ще 19 грудня 1980 р., Конституції України (ст. 24) 22 , одним 3 основних національних законів, метою якого було гарантувати рівні права, можливості чоловіків та жінок у нашій державі, зокрема й у сфері соціального забезпечення, є Закон України «Про забезпечення рівних прав та можливостей жінок і чоловіків» від 8 вересня 2005 р. Відповідно до ст. 6 даного Закону, дискримінація за ознакою статі забороняється. Не вважаються дискримінацією за ознакою статі: спеціальний захист жінок під час вагітності, пологів та грудного вигодовування дитини; різниця в пенсійному віці для жінок і чоловіків, передбачена законом тощо.

Органи виконавчої влади, органи місцевого самоврядування, підприємства, установи й організації рівною мірою повинні враховувати інтереси жінок і чоловіків під час здійснення заходів щодо їх соціального захисту. Погіршення становища осіб будь-якої статі в разі застосування системи соціального страхування, пенсійного забезпечення, соціальної допомоги є неприпустимим (ст. 20) ${ }^{23}$.

3 одного боку, громадян як чоловічої, так і жіночої статі наділено однаковими правами в соціальній сфері та забезпечено де-юре рівні умови їх здійснення. Однак з іншого - гендер передбачає і відмінності та їхні межі у правах і гарантіях, які зумовлені різною статтю людини. Це визначається реальними потребами як чоловіка, так і жінки. Значною своєю частиною це проблема соціальної сфери, де реалізуються соціальні права, зокрема право на пенсійне забезпечення.

В Україні має місце порушення принципу рівності між чоловіками і жінками у сфері пенсійного забезпечення, для цьому є причини. Перелічимо основні 3 них: 1) більше жінок, ніж чоловіків перебувають у вимушених відпустках; 2) більшість серед тих, хто працює неповний робочий день, - жінки; 3) виконання материнської функції перешкоджає службовій кар'єрі та подальшому соціальному забезпеченню; 4) заробітна

22 Конституція України від 28 червня 1996 р. / Верховна Рада України. URL: https://zakon.rada.gov.ua/laws/show/254к/96-вр (дата звернення: 01.11.2020).

23 Про забезпечення рівних прав та можливостей жінок і чоловіків : Закон України від 8 вересня 2005 р. № 2866-IV / Верховна Рада України. URL: https://zakon.rada.gov.ua/laws/ show/2866-15 (дата звернення: 12.02.2020). 
плата в жінок нижча за заробітну плату чоловіків; 5) тривалість їхнього страхового стажу і накопичень також здебільшого менша, що пов'язано 3 материнством; 6) за диференціацією віку раніший вихід на пенсію; 7) у жінок очікувана тривалість життя білыша, ніж у чоловіків, - усе це в сукупності призводить до нижчого рівня пенсійних виплат ${ }^{24}$.

Починаючи iз 2011 р. в Україні відбувається поетапне підвищення і вирівнювання (до пенсійного віку чоловіків) пенсійного віку жінок - з 55 років до 60 років. Багато хто з науковців уважають таке рішення правильним, оскільки воно може мати позитивний вплив на розмір пенсії для жінок ${ }^{25}$. За оцінками експертів, в Україні не існує жодних об'єктивних фізіологічних, економічних чи соціальних підстав для утримання нижчої межі пенсійного віку для жінок. Існуюча раніше п’ятирічна різниця в пенсійному віці та тривалості страхового стажу для жінок і чоловіків була соціально несправедливою і суперечила страховим принципам, адже жінки набували права виходу на пенсію й одержання мінімального розміру пенсії (який є однаковим незалежно від статі) за меншого трудового внеску. Як наслідок, нижча межа пенсійного віку та, відповідно, коротша тривалість стажу зумовлювали нижчий розмір пенсій у жінок ${ }^{26}$.

Установлення єдиного порогу пенсійного віку та необхідного страхового стажу для жінок і чоловіків потрібне не тільки і не стільки для поліпшення фінансової ситуації в Пенсійному фонді, скільки для забезпечення реальної гендерної рівності у трудових і пенсійних правах, розширення можливостей щодо розвитку та реалізації людського (зокрема, трудового) потенціалу населення України. Проте одразу зауважимо, що збільшення пенсійного віку жінок до пенсійного віку чоловіків не означає швидкого або автоматичного зрівняння розмірів їхніх пенсій. Щоби був помітний результат, повинен пройти певний період часу. Окрім цього, не може йтися про «абсолютну рівність» у розмірах пенсій, що апріорі неможливо.

Певний гендерний розрив у рівні пенсійних виплат існуватиме за будь-яких умов, оскільки внаслідок цілого комплексу чинників чоловікам властиво мати в середньому білыші зарплати, а жінки зазвичай

\footnotetext{
24 Копачовець Н. Правові аспекти рівності жінок і чоловіків у сфері соціального забезпечення. URL: https://minjust.gov.ua/m/str_48 (дата звернення: 23.02.2020).

25 Линдюк О. Гендерні підходи у сфері пенсійного забезпечення державних службовців. C. 125-132. URL: http://academy.gov.ua/ej/ej19/PDF/16.pdf (дата звернення: 23.02.2020).

26 Герасименко В. Гендерні невідповідності пенсійної системи в Україні: проблеми та перспективи. URL: http://dspace.nbuv.gov.ua/bitstream/handle/123456789/11787/08Gerasumenko.pdf?sequence=1 (дата звернення: 14.02.2020).
} 
роблять перерву у трудовій діяльності, пов’язану з народженням і вихованням дітей, упродовж якої за них сплачуються мінімальні пенсійні внески. Проте завдяки реалізації цілого комплексу заходів у сфері регулювання оплати праці, насамперед встановлення рівного пенсійного віку для жінок і чоловіків, гендерні відмінності в рівні пенсійного забезпечення можна скоротити. Окрім цього, варто звернути увагу на те, що проблема гендерного пенсійного розриву характерна не лише для України, а і для Великобританії, Кіпру, Нідерландів, Данії, Словаччини тощо.

Одним із важливих інструментів підвищення адекватності пенсій за віком для жінок є додаткові гарантії, які дозволяють поєднувати працю з материнством. У цьому сенсі законодавство України прогресивне, оскільки до страхового пенсійного стажу зараховуються періоди не тільки перебування у відпустках у зв'язку з вагітністю та пологами, а й догляду за дитиною до досягнення нею трирічного віку, у разі отримання допомоги під час таких відпусток ${ }^{27}$.

Необхідно також звернути увагу і на положення ст. 115 Закону України «Про загальнообов'язкове державне пенсійне страхування» щодо різних вимог до віку та страхового стажу для чоловіків і жінок щодо дострокового виходу на пенсію, які, на нашу думку, є необгрунтованими і видаються дискримінаційними. Така ж позиція відображена і в аналітичному звіті, що був розроблений за результатами аналізу регулювання дотримання рівності та недискримінації в доступі до праці, послуг і соціального забезпечення: оцінка стану впровадження Україною антидискримінаційних Директив $\mathrm{CC}^{28}$. Ідеться про такі групи осіб: 1) особи, хворі на гіпофізарний нанізм (ліліпути), диспропорційні карлики; 2) особи з інвалідністю за зором I групи - сліпі й особи з інвалідністю з дитинства I групи; 3) дружини (чоловіки), якщо вони не взяли повторний шлюб, діти, які стали особами з інвалідністю до досягнення повноліття, і батьки, яким надано статус особи, на яку поширюється чинність Закону України «Про статус ветеранів війни, гарантії їх соціального захисту»; 5) військовослужбовці, особи начальницького і рядового складу органів внутрішніх справ, поліцейські, які брали участь

\footnotetext{
27 Яценко В. Чому пенсії у жінок менші і чому так буде ще 200 років. Украйнська правда. URL: https://www.epravda.com.ua/publications/2019/01/9/643934/ (дата звернення: 19.01.2020).

28 Аналіз регулювання дотримання рівності та недискримінації у доступі до праці, послуг та соціального забезпечення: оцінка стану впровадження Україною антидискримінаційних Директив СC : аналітичний звіт за результатами дослідження. Київ, 2019. C. 17. URL: https://www.civic-synergy.org.ua/wp-content/uploads/2018/04/Analiz-regulyuvannya-dotrymannya-rivnosti-ta-nedyskryminatsiyi-u-dostupi-do-pratsi-poslug-ta-sotsialnogo-zabezpechennya.pdf (дата звернення: 18.02.2020).
} 
у бойових діях, в антитерористичній операції в районах іiї проведення, у здійсненні заходів із гарантування національної безпеки і оборони тощо ${ }^{29}$. Вважаємо, що в подібних ситуаціях (у разі встановлення різних вікових меж та страхового стажу для чоловіків і жінок) повинно існувати належне обгрунтування їх диференціації, оскільки інакше це можна розглядати як прояви дискримінації.

Рівні права жінок і чоловіків у сфері зайнятості та праці відіграють важливу роль у забезпеченні рівності прав та можливостей загалом. За даними Державної служби статистики України, між чоловіками та жінками в Україні існує значний гендерний розрив в оплаті праці ${ }^{30}$, що в результаті призводить до великого розриву в розмірах пенсійних виплат.

\section{ВИСНОВКИ}

Обраний Україною курс до євроінтеграції зумовлює політику держави, спрямовану на утвердження загальноправових цінностей, насамперед принципу заборони дискримінації та гендерної рівності. Активний процес реформування законодавства в соціальній сфері, який можна спостерігати протягом останніх років, спрямований на запозичення досвіду Європейського Союзу. Проте, незважаючи на позитивні зміни у векторі розвитку, удосконалення вітчизняного законодавства, залишається ще багато невирішених питань.

Дослідивши прояви дискримінації, зокрема гендерної нерівності, що існують у системі пенсійного забезпечення України, можна стверджувати, що положення Конституції України, ратифікованих міжнародних договорів, угод, конвенцій, законодавчих актів, на жаль, здебільшого мають суто декларативний характер і не підкріплені механізмами реалізації, фінансовими й організаційними ресурсами держави й органів місцевого самоврядування. Такі правові реалії на практиці призводять до порушення прав осіб і спричиняють «парадоксальну» ситуацію, коли базові правові принципи (рівноправності, заборони дискримінації, гендерної рівності), встановлені

\footnotetext{
29 Про загальнообов'язкове державне пенсійне страхування : Закон України від 9 липня 2003 р. № 1058-IV / Верховна Рада України. URL: https://zakon.rada.gov.ua/laws/show/ 1058-15 (дата звернення: 18.02.2020).

30 Аналіз регулювання дотримання рівності та недискримінації у доступі до праці, послуг та соціального забезпечення: оцінка стану впровадження Україною антидискримінаційних Директив СC: аналітичний звіт за результатами дослідження. Київ, 2019. C. 19. URL: https://www.civic-synergy.org.ua/wp-content/uploads/2018/04/Analiz-regulyuvannyadotrymannya-rivnosti-ta-nedyskryminatsiyi-u-dostupi-do-pratsi-poslug-ta-sotsialnogozabezpechennya.pdf (дата звернення: 18.02.2020).
} 
і гарантовані державою, опускаються, виносяться на «другий план». Навіть більше, у законодавчих актах спеціального характеру, що регламентують окремі види та форми соціального забезпечення, принцип рівності загалом і гендерної рівності зокрема не закріплено.

Що стосується гендерної нерівності в межах пенсійної системи, то оскільки остання має комплексний характер, іiї неможливо усунути шляхом подолання лише одного чи двох чинників, що ії спричиняють. У такому разі протидія також повинна бути системною. Наприклад, усунення різниці в пенсійному віці чоловіків і жінок може і не привести до очікуваних результатів, якщо не усунути чинники гендерного дисбалансу, що притаманні сфері зайнятості. Іншою проблемою правового регулювання соціального забезпечення загалом і пенсійного забезпечення зокрема $є$ непряма дискримінація, яку досить часто можна сплутати з диференціацією, та відсутність механізму протидії їй.

\section{АНОТАЦІЯ}

Обраний Україною проєвропейський вектор розвитку покладає на неї зобов'язання щодо утвердження та забезпечення реалізації на практиці загальновизнаних правових цінностей. Будь-яка сучасна держава, яка позиціонує себе як демократична та правова, не може вважатися такою, якщо не здійснює соціально-правову політику щодо запобігання та протидії дискримінації, ґендерної нерівності в усіх сферах суспільного життя. Для України, як і для багатьох країн Європейського Союзу, продовжує залишатися актуальним питання захисту осіб від будьяких проявів дискримінації, утвердження принципу рівності чоловіків і жінок. Першим кроком до вирішення цього питання є розробка й ухвалення відповідних правових актів, ратифікація міжнародних норм.

Проведене правове дослідження дозволило визначити прогресивний розвиток українського законодавства у сфері протидії дискримінації з урахуванням досвіду Європейського Союзу та рекомендацій інших міжнародних організацій. Особлива увага в дослідженні приділяється виявленню проявів дискримінації в пенсійній системі. Так, за результатами дослідження було зроблено висновок, що нормативне закріплення принципу заборони дискримінації та гендерної рівності ще не означає автоматичного припинення порушення прав осіб. Оскільки, окрім гарантування даних принципів, повинен ще існувати механізм їх утвердження на практиці, налагоджена система контролю за проявами дискримінації. Що стосується ґендерної нерівності в пенсійному забезпеченні, то вирішення цієї проблеми також повинно мати 
комплексних характер, бути спрямоване на усунення всіх причин, що призводять до гендерної нерівності.

\section{ЛІТЕРАТУРА}

1. Чічкань М., Бабіч К. Європейські стандарти щодо заборони дискримінації у сфері праці та законодавство України: питання співвідношення. Порівняльно-аналітичне право. 2016. № 5. С. 163-166.

2. Богачева Л. Джерела європейського та національного права. Держсавне будівниитво та місиеве самоврядування. 2012. Вип. 24. C. $17-26$.

3. Про затвердження Державної соціальної програми забезпечення рівних прав та можливостей жінок і чоловіків на період до 2021 р. : постанова КМУ від 11 квітня 2018 р. № 273. База даних «Законодавство України». URL: https://zakon.rada.gov.ua/laws/show/273-2018-п (дата звернення: 24.02.2020).

4. Про затвердження Національного плану дій 3 виконання рекомендацій, викладених у заключних зауваженнях Комітету ООН $з$ ліквідації дискримінації щодо жінок до восьмої періодичної доповіді України про виконання Конвенції про ліквідацію всіх форм дискримінації щодо жінок на період до 2021 р. : розпорядження КМУ від 5 вересня 2018 р. № 634-p. База даних «Урядовий портал». URL: https://www.kmu.gov.ua/npas/pro-go-planu-dij-z-vikonannya-rekomo-zhinokdo-vosmoyi-periodichnoyi-dopovidi-ukrayini-pro-vikonannya-konvenciyipro-likvidaciyu-vsih-form-diskriminaciyi-shchodo-zhinok-na-period-do-2021roku (дата звернення: 15.02.2020).

5. Про внесення змін до деяких законодавчих актів України (щодо гармонізації законодавства у сфері запобігання та протидії дискримінації iз правом Європейського Союзу): проект закону від 20 листопада 2015 p. № 3501 / Верховна Рада України. URL: http://w1.c1.rada.gov.ua/pls/ zweb2/webproc4_1?pf3511=57162 (дата звернення: 19.02.2020).

6. Про загальнообов'язкове державне пенсійне страхування : Закон України від 9 липня 2003 р. № 1058-IV, у редакції від 5 листопада 2008 р. / Верховна Рада України. URL: https://zakon.rada.gov.ua/laws/show/1058-15/ ed20081105 (дата звернення: 17.02.2020).

7. Про пенсійне забезпечення : Закон України від 5 листопада 1991 p. № 1788-XII, у редакції від 1 січня 2008 р. / Верховна Рада України. URL: https://zakon.rada.gov.ua/laws/show/1788-12/ed20080101 (дата звернення: 16.01.2020).

8. Про загальнообов'язкове державне пенсійне страхування : Закон України від 9 липня 2003 р. № 1058-IV / Верховна Рада України. URL: https://zakon.rada.gov.ua/laws/show/1058-15 (дата звернення: 18.02.2020). 
9. Загальна декларація прав людини, прийнята i проголош. резолюцією 217 А (III) Генеральної Асамблеї ООН від 10 грудня 1948 р. База даних «Законодавство України». URL: http://zakon.rada.gov.ua/laws/ show/995_015 (дата звернення: 29.01.2020).

10. Міжнародна конвенція про ліквідацію всіх форм расової дискримінаціївід 21 грудня 1965 р. База даних «Законодавство України». URL: https://zakon.rada.gov.ua/laws/show/995_105 (дата звернення: 01.02.2020).

11. Європейська соціальна хартія від 3 травня 1996 р. База даних «Законодавство Украӥни». URL: https://zakon.rada.gov.ua/laws/ show/994_062 (дата звернення: 15.02.2020).

12. Рішення Конституційного Суду України від 7 жовтня 2009 р. у справі № 1-32/2009. База даних «Законодавство України». URL: https://zakon.rada.gov.ua/rada/show/v025p710-09/ed20150101/ sp:max25?sp=:max25\&lang=ru (дата звернення: 12.02.2020).

13. Про стан додержання та захисту прав і свобод людини і громадянина України : щорічна доповідь Уповноваженого Верховної Ради України з прав людини. 2018 р. 134 c. URL: http://www.ombudsman.gov.ua/ua/page/ npm/info/ (дата звернення: 25.01.2020).

14. Конвенція про захист прав людини і основоположних свобод від 4 листопада 1950 р. База даних «Законодавство Украӥни». URL: https://zakon.rada.gov.ua/laws/show/995_004 (дата звернення: 27.01.2020).

15. Постанова Верховного Суду від 18 вересня 2018 р. у справі № 522/535/17. URL: https://zakononline.com.ua/courtdecisions/show/84621472 (дата звернення: 15.01.2020).

16. Про свободу пересування та вільний вибір місця проживання в Україні : Закон України від 11 грудня 2003 р. № 1382-IV / Верховна Рада України. URL: https://zakon.rada.gov.ua/laws/show/1382-15 (дата звернення: 17.01.2020).

17. Рішення Свропейського суду з прав людини у справі «Пічкур проти України» від 7 листопада 2013 р. заява № 10441/06. База даних «Законодавство України». URL: https://zakon.rada.gov.ua/laws/ show/974_984 (дата звернення: 29.01.2020).

18. Постанова Верховного Суду від 1 жовтня 2019 р. у справі № 804/3646/18. Юридичний інтернет-ресурс «Протокол». URL: https:/protocol.ua/ua/vs_kas_ukrainskiy_pensioner/ (дата звернення: 11.01.2020).

19. Гендерна політика Європейського Союзу: загальні принципи та найкращі практики. Київ, 2015. Міжнародний центр перспективних досліджень (МЦПД). 44 с. URL: http://www.icps.com.ua/assets/uploads/ files/genderna_pol_tika_s.pdf (дата звернення: 25.02.2020). 
20. Конституція України від 28 червня 1996 р. / Верховна Рада України. URL: https://zakon.rada.gov.ua/laws/show/254к/96-вр (дата звернення: 01.11.2020).

21. Про забезпечення рівних прав та можливостей жінок і чоловіків : Закон України від 8 вересня 2005 р. № 2866-IV / Верховна Рада України. URL: https://zakon.rada.gov.ua/laws/show/2866-15 (дата звернення: 12.02.2020).

22. Копачовець Н. Правові аспекти рівності жінок і чоловіків у сфері соціального забезпечення. URL: https://minjust.gov.ua/m/str_48 (дата звернення: 23.02.2020).

23. Линдюк О. Гендерні підходи у сфері пенсійного забезпечення державних службовців. С. 125-132. URL: http://academy.gov.ua/ej/ej19/ PDF/16.pdf (дата звернення: 23.02.2020).

24. Герасименко В. Гендерні невідповідності пенсійної системи в Україні: проблеми та перспективи. URL: http://dspace.nbuv.gov.ua/ bitstream/handle/123456789/11787/08Gerasumenko.pdf?sequence=1 (дата звернення: 14.02.2020).

25.Яценко В. Чому пенсії у жінок менші і чому так буде ще 200 років. Українська правда. URL: https://www.epravda.com.ua/ publications/2019/01/9/643934/ (дата звернення: 19.01.2020).

26. Аналіз регулювання дотримання рівності та недискримінації у доступі до праці, послуг та соціального забезпечення: оцінка стану впровадження Україною антидискримінаційних Директив $\mathrm{CC}$ : аналітичний звіт за результатами дослідження. Київ, 2019. 51 с. URL: https://www.civic-synergy.org.ua/wp-content/uploads/2018/04/Analizregulyuvannya-dotrymannya-rivnosti-ta-nedyskryminatsiyi-u-dostupi-do-pratsiposlug-ta-sotsialnogo-zabezpechennya.pdf (дата звернення: 18.02.2020).

Information about authors: Bodnaruk M. I., LL. D., Professor of the Department of Private Law Yuriy Fedkovych Chernivtsi National University 2, Kotsyubynsky str., Chernivtsi, 58012, Ukraine

Burka A. V., Assistant of the Department of Private Law Yuriy Fedkovych Chernivtsi National University 2, Kotsyubynsky str., Chernivtsi, 58012, Ukraine

DOI https://doi.org/10.30525/978-9934-588-43-3/1.24 